\title{
THE ROLE OF NURSES AND PATIENTS' INVOLVEMENT IN THE CLINICAL DECISION-MAKING PROCESS
}

Diana Catarina Ferreira de Campos ${ }^{1}$ João Manuel Garcia do Nascimento Graveto ${ }^{2}$

Campos DCF, Graveto JMGN. The role of nurses and patients' involvement in the clinical decision-making process. Rev Latino-am Enfermagem 2009 novembro-dezembro; 17(6):1065-70.

This paper is a literature review based on articles in the nursing field about shared clinical decision. The objectives are to examine the role of nurses and patients in the decision-making process in the context of clinical practice. To support these themes, a review of recent literature was conducted with the following results: patients prefer shared decision-making with professionals who should support and provide information to patients in order to overcome the barriers hampering patients' involvement in decision-making. There is a clear need for more research studies that address the problems in the clinical decision-making process so as to contribute to healthcare improvement.

DESCRIPTORS: nursing, personal autonomy, information, decision making

\section{PAPEL DEL ENFERMERO Y PARTICIPACIÓN DEL CLIENTE EN EL PROCESO DE TOMA DE DECISIONES CLÍNICAS}

El presente trabajo es de revisión de literatura, está basado en artículos de investigación del área de enfermería, abordando el tema: decisión clínica compartida. Los objetivos fueron dirigidos a analizar el papel del enfermero y del paciente en el proceso de la toma de decisiones en contextos de la práctica clínica. Para fundamentar esas temáticas, se hizo una revisión de la literatura reciente, la que reveló los siguientes resultados: los pacientes prefieren compartir la toma de decisiones con los profesionales y los profesionales deben apoyar $y$ dar información a los clientes de forma a diluir las barreras que dificultan su participación en el proceso de decisión. Quedó clara la necesidad de realizar más estudios que presenten evidencias problemáticas en el proceso de decisión en el contexto clínico, con la finalidad de contribuir para la evolución de los cuidados.

DESCRIPTORES: enfermería; autonomía personal; información; toma de decisiones

\section{PAPEL DO ENFERMEIRO E ENVOLVIMENTO DO CLIENTE NO PROCESSO DE TOMADA DE DECISÃO CLÍNICA}

O presente trabalho é de revisão de literatura, baseada em artigos de investigação da área da enfermagem, abordando o tema: decisão clínica partilhada. Os objetivos estão direcionados para o analisar do papel do enfermeiro e do paciente no processo de tomada de decisão em contextos da prática clínica. Para fundamentar essas temáticas, fez-se revisão de literatura recente que revelou os seguintes resultados: os pacientes preferem partilhar a tomada de decisão com os profissionais e os profissionais devem apoiar e dar informação aos clientes de forma a diluir as barreiras que dificultam o seu envolvimento no processo de decisão. Ficou clara a necessidade de mais estudos que evidenciem problemáticas no processo de decisão em contexto clínico, no sentido de contribuir para a evolução dos cuidados.

DESCRITORES: enfermagem; autonomia pessoal; informação; tomada de decisões

Escola Superior de Enfermagem de Coimbra, Portugal:

${ }^{1}$ Undergraduate Student, Nursing Diploma Program, e-mail: dicatarinafcampos@hotmail.com. ${ }^{2}$ Adjunct Professor, Ph.D. in Development and Psychological Intervention, e-mail: jgraveto@esenfc.pt. 


\section{INTRODUCTION}

During the clinical practice, nursing professionals face a number of different situations involving patients with different and very distinct problems and health care needs. Thus, the clinical decision-making process is a vital component of nursing practice.

The clinical decision is a process which includes both the clinical diagnosis and assessment and the decision on what to do ${ }^{(1)}$. In addition, the decision-making process in nursing clinical practice is understood as a series of decisions made by nurses in interaction with the patient regarding (a) the type of observations to be made in the client situation, (b) the evaluation of the data observed and derivation of meaning (diagnosis), and (c) nursing actions that should be taken with or on behalf of the client. This definition reveals the stages of the Nursing Process, stressing the importance of interacting/sharing with the client ${ }^{(2)}$. It should be noted that the term "clinical decision" has been defined as a choice between alternatives in which the main issue is the choice of a particular course of action ${ }^{(3)}$.

The growing autonomy, the information and the involvement of patients are at the heart of a patient-focused health policy ${ }^{(4)}$. Hence, patient participation becomes critical for the effective quality of nursing care.

The research question guiding this study is: what are the contributions of research to an understanding of the nursing process of shared decision-making in clinical practice? This study aimed to examine both the role of nurses and patients in the decision-making process in the context of clinical practice. This paper is based on research and review of recent international literature. The authors of the research studies presented here ${ }^{(4-6)}$ tried to reflect on the knowledge available in the area of clinical decision, especially focusing on the role that nurses should undertake and on patient involvement. Another reference literature will be used to contextualize and support the shared decision-making process in clinical context.

\section{METHODOLOGY}

The search was conducted using the following descriptors in English: decision-making, shared decision-making, autonomy, patient, nursing. The databases searched were: PubMed, MEDLINE, Cumulated Index of Nursing and Allied Health Literature (CINAHL), ProQuest and SciELO.

The search resulted in fifty original articles and review articles. These articles were initially selected to determine their relationship with the decision-making process in clinical practice and the shared decision-making process, and, at a later stage, if they were a product of research, systematic literature review or meta-analysis. They were further revised so as to obtain recent articles, using the following inclusion criteria: review articles using recent literature, and published and carefully referenced research studies. Another inclusion criterion was that they had to include different populations to provide an overview of the topic.

After critical appraisal, three international reference articles ${ }^{(4-6)}$ were selected, providing the basis for discussing this issue and representing scientifically relevant research studies which may contribute to this topic. Some aspects related to shared decision-making were highlighted in the selected articles, and data were interpreted based on relevant literature on the subject ${ }^{(1-3,7-19)}$.

\section{PRESENTATION AND DISCUSSION OF RESULTS}

Health, autonomy and shared clinical decision-making

The World Health Organization defines health as a state of complete physical, mental and social well-being and not merely the absence of disease or infirmity ${ }^{(7)}$. There is a strong tendency to overestimate the physical dimension, probably because it is easier to evaluate and objectify. However, this may inevitably lead to the exclusion of patient involvement in health care ${ }^{(6)}$.

The term "autonomy" has been used with different meanings. However, in contemporary moral philosophy, there are two conditions necessary for it to be used: the condition of freedom - independence from others - and the ability to act intentionally - i.e. without any type of coercion. This does not convey the idea that an autonomous action is one in which the individual acts free from outside influences because the very condition of the patient impedes the full exercise of independent will. Nevertheless, 
patients continue autonomous since they are still able to reject or accept demands from others ${ }^{(8)}$.

The principle of autonomy is the one posing more challenges to Hippocratic ethics ${ }^{(8)}$ because sometimes major conflicts emerge in the patient/ health professional relationship when patients try to exercise their right to autonomy and the physician wants to use the paternalistic approach, based on the principle of beneficence. This is the era of accountability for one's own choices and, as a direct consequence, there is an approach to informed consent, i.e. patients will assume more responsibility for their own health instead of delegating it to physicians ${ }^{(4)}$. The patient's position is shifting to a client's position, with a clear increase in the amount of rights and personal choices, excellence in health care and right to self-determination ${ }^{(7)}$.

The clinical decision-making process should be shared among health professionals, patients and probably their families. The research ${ }^{(4)}$ underlines the last two groups, maintaining that they should receive information, support and specialized care to be able to manage their condition. This idea is reinforced by the assumption that the exercise of autonomy exists when knowledge and information are shared between health teams and patients, offering important data, in accessible language, for any decision to be made consciously ${ }^{(9)}$.

Communication and decision-making

Communication is the process of transmitting messages and interpreting their meaning. Human relationships and communication with the patients are the heart and soul of the work in Nursing (7). Theoretically, a good communication empowers others and contributes to a better understanding of people and their own choices ${ }^{(7)}$.

For an effective clinical decision, information is essential: it gives power of control to the client and is comforting, because the client knows what to expect ${ }^{(4)}$.

International authors (4) confirm the importance of an effective communication, stating that if health professionals do not focus their attention on how they communicate, they may limit patient's choices and confusion will take over. For example, when a health professional talks to a cancer patient about the hospital protocol treatment, he/she may easily regret what was said because obviously the patient cannot understand the complexity of the concepts. Considering this, it is critical that nurses are aware and able to adapt their language to each patient, taking into account that the individual is part of the clinical decision-making process ${ }^{(4)}$.

Making a clinical decision is a criterion, a skill which distinguishes a nurse from other professionals without degrees ${ }^{(7)}$. This power to decide in clinical context has become a key feature increasingly required for today's nurses ${ }^{(7,10)}$. In Nursing, health care decisions may fall under two conflicting scenarios: the decision-making may be focused on the nurse's goals, with the decision being taken by others, by and for the person and his/her condition; or the decision is taken with and for the client, by negotiating strategies and defining the outcomes together ${ }^{(11)}$.

This author maintains that there should be a rejection of the work methods which limit the nurse's decision, because they have narrowly focused their practices on the user from an organic point of view. Thus, the author suggests that one should use a process of care which "(...) makes it possible to create and test solutions within the scope of nursing that meet the expectations of the beneficiaries" (11).

Nurse's role and client's involvement in decisionmaking

The clinical decision underlying health care is essential for the excellence and quality of nursing care. Health professionals have an in-depth knowledge of the diseases, whereas patients are the experts in their beliefs, values and preferences. It follows that the identification of these issues is increasingly relevant as the stay in hospitals and/or health services is short and the demands for excellence in health care are increasing (6)

Given the relevance of this topic, international researchers have tried to better understand nurse's role and client's involvement in the clinical decisionmaking process (4-6). Thus, it was considered appropriate to use three current research studies so as to better explain the importance of shared decisionmaking. In the first study ${ }^{(4)}$, developed in the United Kingdom, the sample was composed of 35 active health professionals (nurses, physicians and other health professionals in primary and secondary health care). The main goal of this research was to explore the different views of client's participation in the decision-making process described by health professionals. Another study ${ }^{(5)}$, conducted in Ontario 
(Canada), sought to understand the role that clients prefer to play in clinical decision-making. To this end, the sample was composed of a number of people with various diseases - some chronic, some acute - and, as a control group, nursing students were selected. Finally, another author ${ }^{(6)}$ developed a research study which explored the clinical decision-making process in nursing, with a special focus on the quality of diagnoses, client participation and concordance between clients and nurses' perceptions of the clients' needs and favourite role in decision-making. This research study included the participation of patients and nurses from various hospitals in Sweden (randomly selected during the study period - between 1999 and 2006). The main findings of the different studies are described in this paper.

As an interesting topic nowadays, shared clinical decision has a unique value, both for patients, who feel more confident, and nurses, who see their profession dignified. However, it is acknowledged that while some patients choose to adopt a policy of balance between the interests of health professionals and their own interests, as a person, others prefer to take control, choosing their course of action, or adopt a more passive attitude. Therefore, the author argues that patients were characterized as passive in terms of their preferences to participate in the decisions about physical and psychological health care ${ }^{(4)}$. However, the author reinforces that nurses realized that patients could play a more active role, choosing, for example, their own diet according to therapeutic indications ${ }^{(4)}$.

According to the previous author ${ }^{(4)}$, there are four conflicting models of nurse-client interaction: a paternalistic model in which health professionals make decisions by the patient; an informative model in which health professionals provide information to the client who makes the choice; an interpretative model in which nurses and clients interact to identify the preferences of the latter and health professionals support decisionmaking; and a deliberative model which is very similar to the interpretative model, but that adds a moral dimension underlining the discussion of alternatives between partners ${ }^{(12)}$.

The deliberative model is explored by a researcher, supporting the bilateral exchange of information between clients and health professionals so that client's preferences are taken into account in reaching an agreement on the choice to make ${ }^{(6)}$.
The above-mentioned author ${ }^{(6)}$ asserts that patient participation is related to the concepts of power and empowerment. Thus, power is seen as something external to the individual, indicating that an increase in the power of some people must be balanced with a decrease of the power of other people. The prerequisites for client involvement in the decisionmaking process are opportunities and available information. Empowerment is advocated as a process by which people gain control over their lives. At the heart of this concept is the idea that it is desirable and possible for people to gain control over their lives and be empowered to collaborate in the processes of change ${ }^{(13)}$. Two North American researchers ${ }^{(14)}$, in a study on the relationship between empowerment and treatment of diabetes, found that clients with power to intervene in their own disease achieve significant health gains. Therefore, it must be underlined that patients should be active in their empowerment, because nurses have weak and fruitless results when trying to empower patients. The major role of nurses is to facilitate and support empowerment ${ }^{(6)}$. A Portuguese author ${ }^{(15)}$ reinforces this idea, saying that a nurse should be someone who provides the necessary information, creating a positive and formative environment, and a counsellor, helping the patient explore feelings and thoughts and encouraging the identification and analysis of past problems.

Another study ${ }^{(4)}$ points out the distinction between patients who wait for information and are guided to the right treatment and those who assume the responsibility of choosing one of the available alternatives. Although there is this difference of preferences, the authors conclude that providing room and opportunity for patients to choose who has the final word is an essential component of decisionmaking, because in any case there is some level of participation and control over the situation.

The above-mentioned authors ${ }^{(4)}$ intend to clarify that both diagnosis and treatment are traumatic for patients. Although understanding the information has been considered a prerequisite for the effectiveness of the clinical decision-making process, the study participants ${ }^{(4)}$ reported that patients should not be pressured to process such a huge amount of information at such a stressful time, because, for example, if the patient is diagnosed with colon cancer, he/she will only want it to be removed, probably choosing the more radical treatment when 
the solution could be the use of more conservative techniques. However, the results from this study also show that appropriate and timely information, adapted to the individual needs of each patient, is essential to facilitate their involvement in decision-making and reduce anxiety ${ }^{(4)}$.

Another study was conducted by researchers (5) who interviewed a group of people (who sought health care at the hospitals in the region of Ontario, Canada) and divided them into two groups: those who sought health care because they felt a chest pain (which the authors call chest pain vignette) and those who sought because of their health condition at the moment (which the authors call current health vignette). According to the study results, only $1 \%$ of the current health vignette and $0.6 \%$ of the chest pain vignette preferred an autonomous role in decisionmaking. However, the authors report that most of them answered that they would not choose a passive role either. Thus, the study reveals a strong preference throughout the entire sample for shared decisionmaking in clinical context. This preference is higher in the current health vignette $(78.1 \%)$ than in the chest pain vignette $(65.2 \%)$. Based on these results, the author suggests that adapting to and becoming familiar with the health status enables patients to participate and share the decision-making process ${ }^{(5)}$.

According to these results, the authors ${ }^{(5)}$ concluded that there is a strong preference for sharing the clinical decision - patients want to be involved in the selection process, which will certainly affect their quality of life. However, according to the authors, patients do not want to be completely responsible for the decision. On the contrary, they are willing to leave much of the responsibility for tasks that require specific knowledge to health professionals.

Similar to the opinion of the previous author, it is argued and supported that nurses have inevitably the main responsibility to integrate patients as active partners in the decision-making process in nursing, because patients are in a dependent position and cannot be expected to take the lead. The results of study conducted in Sweden show that 9\% of patients prefer an active role in decision-making, 30\% want to share the decision with the nurse, and $64 \%$ delegate decisionmaking to professionals - these authors mention that the patient's choice of a passive role in clinical decision is a deliberate action, which indicates that it is not at all a passive attitude, but rather an effective choice of a role without direct intervention ${ }^{(6)}$.
Already in 1996, an author ${ }^{(16)}$, using a case study as illustration, demonstrated that the active participation of patients in health assistance is essential to encourage them to self care. Thus, the author proposed an interrelation which promotes both patient's and nurse's autonomy in the sense that they both actively participate in the nursing process.

The key idea of implementing the nursing process as a model for solving patients' problems considers that the interventions may be adapted to the patients. However, to be able to do this, nurses need to understand patients' needs. Therefore, the key to this issue is the nurse-patient interaction, in which the information is shared and the communication works in both directions ${ }^{(7)}$.

\section{CONCLUSION}

This paper presents a new perspective on the decision-making process in clinical practice, enabling professionals to apply their decision practices in clinical practice. Some authors ${ }^{(17)}$ have discussed the use of evidence-based practice for nursing diagnostic reasoning. However, based on literature review, it is clear that nurses sometimes underestimate the importance of patients' needs ${ }^{(4-6)}$, analysing the clinical decision-making process taking only into account the objectives of the professional team. The discussion focuses on decision diagrams, and the multiplicity of the patients and their social context are ignored. For nurses to care for others, they first need to demonstrate that they know the limits of their practice and can respect the other as someone different from themselves ${ }^{(18)}$. In a structured reflection on clinical bioethics ${ }^{(19)}$, it is argued that the better the clinical information available, the more qualified will be the decision. However, the policies should not indicate a single course of action for health care - variations which may be more appropriate to individual circumstances should be explored. In addition, family members should always be involved in that decision.

In this paper, it is argued that the decisions in clinical setting should include the assessment of available resources, the patient's wishes, the nurses' cognitive knowledge of their practice, and also the knowledge produced by research. The best analysis of decision-making, as clinical guideline or acting policy, will only fill in some gaps in the decision-making process. This literature review complements the nursing 
assessment and the decision policies discussed by some authors ${ }^{(17)}$, but cannot replace them.

It would be of interest to study the variability in nursing practice in terms of the consistency with clients' perceptions and preferences to participate in decision-making in clinical practice. In conclusion, the

\section{REFERENCES}

1. Ennis RH. Critical thinking Upper Saddle River, NJ: Prentice Hall; 1996.

2. Tanner CA. Teaching clinical judgment. In: Fitzpatrick JJ \& Taunton RL (Editors). Annual Review of Nursing Research. New York: Springer; 1987. p. 153-73.

3. Dowie J. Clinical decision analysis: background and introduction. Analysing how we reach clinical decision. In: Llewelyn $\mathrm{H}$, Hopkins A (Editors). London: Royal College of Physicians; 1993.

4. Beaver K, Craven O, Withman G, Tomlinson M, Susnerwala $S$, Jones $D$, et al. Patient participation in decision making: views of health professionals caring for people with colorectal cancer. J Clin Nurs 2007; 16:725-33.

5. Deber BR, Kraetschmer N, Urowitz S, Sharpe N. Do people want to be autonomous patients? Preferred roles in treatement decision-making in several patient populations. J Compil 2007; 10:248-58.

6. Florin J. Patient participation in clinical decision making in nursing: a collaborative effort between patients and nurses. [S.I.]: Heinz Merten; 2007

7. Perry AG, Potter PA. Fundamentos de Enfermagem : Conceitos e Procedimentos. 5. ed. Loures: Lusociência; 2006. 1106 p.

8. Almeida J. Da Moral Paternalista ao Modelo de Respeito à Autonomia do Paciente: os Desafios para o Ensino da Ética Médica. Rev Bras Educ Méd 2000 janeiro /abril; 24(1):27-30.

9. Neves MP, Pacheco S. Para uma Ética de Enfermagem. 1. ed. Coimbra: Gráfica de Coimbra; 2004. 578 p.

10. Gurbutt R. Nurses' Clinical Decision Making. Radcliffe Publishing; 2006 133p. following questions may be the basis for further research: does the nurse maintain the same level of agreement with the clients, regardless of the type of care or needs over time? What factors may influence the accuracy of the assessment of patients' perceptions?
11. Longarito $C$. O processo de cuidados: a decisão em enfermagem. Informar 1999 abril / junho Porto; $5(17): 18-20$.

12. Charavel M, Bremond A, Moumjid-Ferdjaoui N, Mignotte $\mathrm{H}$, Carrere $\mathrm{M}$. Shared decision-making in question. PsychoOncol 2001 (10):93-102.

13. Rodrigues M, Pereira A, Barroso T. Educação Para a Saúde: Formação Pedagógica de Educadores de Saúde. FORMASAU - Formação e Saúde; 1995. 155 p.

14. Feste C, Anderson R. Empowerment: from philosophy to practice. Patient Educ Cousell 1995; (26):139-44.

15. Ferreira IMG. Nada a perder. Nursing 2003; (182):20-1.

16. Sadala MLA. Autonomia/mutualidade na assistência de enfermagem. Rev Latino-Am Enfermagem [série online]. [Acesso em: 07 março 2009] 1996; 4(1). Disponível em: http://www.scielo.br/scielo.php?script=sci_abstract\& pid $=S 0104-11691996000100010 \&$ Ing $=p t \& n r m=i s o \& t$ Ing $=$ pt

17. Cruz DALM, Pimenta CAM. Prática baseada em evidências, aplicada ao raciocínio diagnóstico. Rev LatinoAm Enfermagem [série online]. [Acesso 07 Março 2009] 2005; 13(3). Disponível em: http://www.scielo.br/ scielo.php?script=sci_abstract\&pid=s0104$11692005000300017 \& \mathrm{lng}=\mathrm{pt \& nrm}=\mathrm{iso} \& \mathrm{t}$ Ing $=p t$

18. Valéria L, Wilson DLF, Rosemary SS, Narciso VS, Jussara ML. O cuidado de si como condição para o cuidado dos outros na prática de saúde. Rev Latino-Am Enfermagem [série online]. [Acesso 07 março 2009] 2004; 12(6). Disponível em: http:/ /www.scielo.br/scielo.php?script $=$ sci_arttext\&pid $=$ S0104$11692004000600013 \& \mathrm{lng}=$ pt\&nrm =iso\&tlng =pt 19. Ribeiro CDM, Rego S. Bioética clínica: contribuições para a tomada de decisões em unidades de terapia intensiva neonatais. Cienc Saúde Colectiva. 2008; 13:2239-46. 